JURNAL ILMIAH KOMPUTERISASI AKUNTANSI, Vol. 14, No. 2,Desember 2021, pp.435 - 442

p-ISSN : 1979-116X (print)

e-ISSN : 2614-8870 (online)

http://journal.stekom.ac.id/index.php/kompak

page 435

\title{
THE INFLUENCE OF GOOD CORPORATE GOVERNANCE ON \\ PROFITABILITY IN CONSUMER GOODS INDUSTRY COMPANIES LISTED ON THE INDONESIA STOCK EXCHANGE IN 2019 - 2020
}

Tri Nur Rohmah

trinur@poltekapi.ac.id

Politeknik API Yogyakarta

\begin{tabular}{|c|c|}
\hline ARTICLE INFO & \\
\hline $\begin{array}{l}\text { Article history: } \\
\text { Received } 30 \text { September } 2021 \\
\text { Received in revised form } 2 \text { Nov } 2021 \\
\text { Accepted } 10 \text { Nov } 2021 \\
\text { Available online } 1 \text { Des } 2021\end{array}$ & $\begin{array}{l}\text { This research on profitability aims to examine the } \\
\text { effect of good corporate governance on } \\
\text { profitability. The population in this research are } \\
\text { Consumer Goods Industry companies listed on the } \\
\text { Indonesia Stock Exchange in } 2019-2020 \text {. The } \\
\text { sample in this research was selected through } \\
\text { purposive sampling, so that a sample of } 104 \\
\text { companies was obtained. The statistical test tool } \\
\text { uses multiple regression analysis. Profitability in } \\
\text { this research was measured using Return on } \\
\text { Assets, while good corporate governance was } \\
\text { measured using external ownerships. The results } \\
\text { show that external ownerships has no significant } \\
\text { positive effect on profitability. }\end{array}$ \\
\hline
\end{tabular}

Keywords: good corporate governance, external ownerships, profitability, Return on Asset

\section{ABSTRACT}

\section{Introduction}

According to Rini and Ghozali (2012), Corporate Governance is explains the relationship between various participants in the company to determine the direction of the company's performance. Corporate Governance itself is generally defined by the International Finance Corporation ("IFC") as "the structures and processes for the direction and control of companies. Based on this understanding, in essence, corporate governance discusses how a company is directed and managed so that all stakeholder interests are properly accommodated. Therefore, the company must be managed in a balanced and good manner, so that the term Good Corporate Governance ("GCG") arises.

Regulation of the Minister of State for State-Owned Enterprises No. PER-01/MBU/2011 defines good corporate governance as the principles that underlie a process and mechanism for managing a company based on laws and regulations and business ethics. In the principles of corporate governance published by the Organization for Economic Co-operation and Development (OECD CG Principles) it is stated that the corporate governance framework should promote transparency 
and efficient markets, comply with legal regulations, and clearly divide obligations and responsibilities. among authorities carrying out supervisory, regulatory and law enforcement functions (OECD, 2004).

External ownership is an external mechanism of corporate governance. Candradewi and Sedana (2016) state that a large proportion of public ownership can increase management's supervisory efforts to prevent managers' opportunistic behavior and can assist company decision making, so as to improve the company's financial performance as measured by ROA. Research from The Indonesian Institute for Corporate Governance (IICG), 2002 (in Rini and Ghozali, 2012) found that the main reason companies implement Good Corporate Governance is compliance with regulations. The company believes that the implementation of Good Corporate Governance is another form of enforcing business ethics and work ethics which has long been a commitment of the company, and the implementation of Good Corporate Governance is related to improving the company's image. Companies that practice Good Corporate Governance will experience an image improvement, and an increase in company value. So in this research will be analyzed, whether the practice of corporate governance can affect the company's performance.

Financial performance is part of the company's economic performance because the measurement scope is more comprehensive and focuses on the financial value achieved by the company covering assets, liabilities and equity, as well as net income which is the company's income. With financial performance, the financial condition of a company can be measured in one reporting period, this financial condition is the basis for managers' decision making to make disclosures. Because in making disclosures, of course, costs are not small. Companies will consider the costs and benefits that will be obtained when they decide to make social and environmental information disclosures (Fr. Retno, 2006 in Rini and Ghozali, 2012). Financial performance in this research will be measured using profitability.

\section{Research Method}

The agency relationship perspective is the basis used to understand corporate governance. Jensen and Meckling (1976) state that the agency relationship is a contract between the manager (agent) and the investor (principal). The conflict of interest between the owner and the agent occurs because the agent may not always act in the interests of the principal, thus triggering agency costs. According to Darmawati et al. (2005) in Rini and Ghozali (2012), the essence of the agency relationship is the separation between ownership (principal/investor) and control (agent/manager). Ownership is represented by investors delegating authority to agents in this case managers to manage investors' wealth. Investors have the hope that by delegating the management authority, they will benefit by increasing the wealth and prosperity of investors. Corporate Governance, which is a concept based on agency theory, is expected to function as a tool to give investors' confidence that they will receive a return on the funds they have invested.

Corporate governance is concerned with how investors believe that managers will benefit them, believe that managers will not steal/embezzle or invest in unprofitable projects related to funds/capital that have been invested by investors, and is related to how investors investors control managers (Shleifer and Vishny, 1997 in Rini and Ghozali, 2012). In other words, corporate governance is expected to function to reduce or reduce agency costs. According to Rini and Ghozali (2012), Corporate Governance arises because it is in the company's interest to ensure to the funders (principals/investors) that the funds invested are used appropriately and efficiently. In addition, with Corporate Governance, the company provides assurance that the management

JURNAL ILMIAH KOMPUTERISASI AKUNTANSI Vol. 14, No. 2, Desember 2021 : $435-442$ 
(agent) acts in the best interests of the company. The Forum for Corporate Governance in Indonesia/FCGI (2001b) defines Corporate Governance as a set of regulations that regulate the relationship between shareholders, company management, creditors, government, employees and other internal and external stakeholders related to the rights and their obligations, thereby creating added value for all interested parties (stakeholders). The added value in question is that Corporate Governance provides effective protection for investors in obtaining a fair and high value return on their investment.

According to Rini and Ghozali (2012), the notion of performance is a description of the achievement of the implementation of a project activities or programs or policies in realizing the goals, objectives, mission and vision of the organization. Performance reporting is a reflection of the obligation to present and report the performance of all activities and resources

need to be held accountable. Performance appraisal is the determination of operational, organizational and organizational effectiveness employees based on predetermined goals, standards and criteria previously periodically. There are two forms of performance, namely operational performance and financial performance. Operational performance is more emphasized on the importance of internal company such as branch or division performance as measured by speed and discipline. Meanwhile, financial performance is usually measured through financial ratios and company share prices in the capital market (Mulyadi, 1999 in Rini and Ghozali, 2012).

According to Rini and Ghozali (2012), the notion of performance is a description of the achievement of the implementation of a project activities or programs or policies in realizing the goals, objectives, mission and vision of the organization. Performance reporting is a reflection of the obligation to present and report the performance of all activities and resources

need to be held accountable. Performance appraisal is the determination of operational, organizational and organizational effectiveness employees based on predetermined goals, standards and criteria previously periodically. There are two forms of performance, namely operational performance and financial performance. Operational performance is more emphasized on the importance of internal company such as branch or division performance as measured by speed and discipline. Meanwhile, financial performance is usually measured through financial ratios and company share prices in the capital market (Mulyadi, 1999 in Rini and Ghozali, 2012).

The implementation of Corporate Governance provides four benefits (FCGI, 2001), namely: (1) improving company performance through the creation of a better decision-making process, increasing company efficiency, and further improving services to stakeholders, (2) making it easier to obtain cheaper financing funds. and not solid (because of the trust factor) which will ultimately increase corporate value, (3) restore investor confidence to invest in Indonesia, and (4) shareholders will be satisfied with the company's performance because it will increase shareholders' values and dividends at the same time.

Profitability is the company's ability to generate profits within a certain period and is an important aspect that can be used as a reference by investors or owners to assess management performance in managing a company (Putri and Azizah, 2019, in Puspa et al, 2021). Profitability is the company's ability to generate profits within a certain period related to sales, total assets, and own capital (Sartono, 2010:122, in Putri and Azizah, 2019). In this research, profitability is proxied

THE INFLUENCE OF GOOD CORPORATE GOVERNANCE ON PROFITABILITY IN CONSUMER GOODS INDUSTRY COMPANIES LISTED ON THE INDONESIA STOCK EXCHANGE IN 2019 - 2020 (Tri Nur Rohmah) 
using Return On Assets (ROA) because Return On Assets shows the ability of the capital invested in all assets owned to generate profits (Kasmir, 2014:201, in Putri and Azizah, 2019). Return on Assets provides information on how efficient a company is in carrying out its business activities. The resulting numbers show what the company can do with what it has. The higher the Return on Assets, the higher the company's ability to generate profits or it means that the position of the owner of the company is getting stronger (Brigham and Houston, 2011: 133, in Putri and Azizah, 2019).

Figure 1. Research Framework

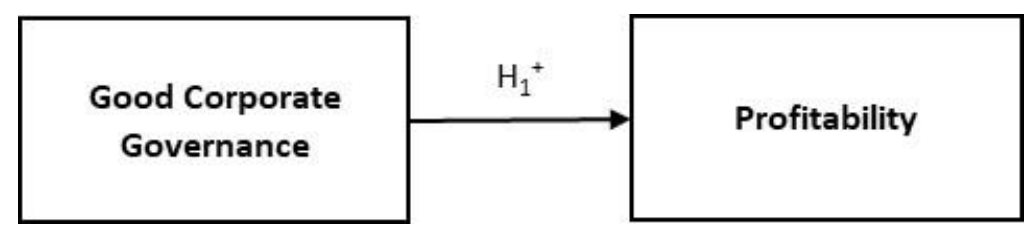

Source: Processed secondary data, 2022

The population is a collection of elements that have certain characteristics that can be used to make conclusions (Chandrarin, 2017). This research uses a population of consumer goods industry companies listed on the Indonesia Stock Exchange in 2019 - 2020. The sample is a collection of subjects that represent the population (Chandrarin, 2017). The sampling in this research used purposive sampling, namely the sampling method based on certain criteria (Chandrarin, 2017). The sampling in this research used purposive sampling with certain criteria so that a sample of 104 consumer goods industry companies listed on the Indonesia Stock Exchange in 2019 - 2020. The type of data based on the data source used in this research is secondary data. Chandrarin (2017) states that secondary data is data that comes from parties or institutions that have used or published it so that testing the validity and reliability of secondary data is not necessary. This research used secondary data in the form of 2019 - 2020 financial statements on the IDX. The data is obtained by downloading the financial statements and other related information from the IDX official website. The method used to collect data in this research is the documentation method. According to Sugiono (2015) documentation is a method used to obtain data and information in the form of books, archives, documents, writings, numbers and images in the form of reports and information that can support research. In this research, data were obtained by downloading financial reports from the official website of the Indonesia Stock Exchange.

To determine the effect of Good Corporate Governance on profitability, multiple regression analysis method was used with the following regression equation:

$\mathrm{PROF}=\alpha+\beta . G C G+\mathrm{e}$

Explain :

PROF = Profitability

GCG = Good Corporate Governance

$\alpha \quad=$ intersep model

$\beta \quad=$ regression koefisien

$\mathrm{e} \quad=$ error residual

Variables and Operational Definitions

JURNAL ILMIAH KOMPUTERISASI AKUNTANSI Vol. 14, No. 2, Desember $2021: 435-442$ 
Chandrarin (2017) defines a variable as something or anything that has value and can be measured, both tangible and intangible. Variables must be clearly defined both conceptually and operationally, in other words, variables must be measurable. The variables used in this research are:

\section{Independent Variable}

The independent variable is a variable that is thought to have an effect on the dependent variable (Chandrarin, 2017). The independent variable in this research is Good Corporate Governance which is measured by the percentage of ownership by externals. Kartika and Puspa (2013) state that external ownership is share ownership by parties outside management or parties who have special relationships with the company. Every company must ensure that the principles of GCG are applied to every aspect of the business and at all levels of the company. The more ownership from outside parties, the higher the demands for the implementation of GCG within a company so that management performance can be achieved. With the implementation of GCG in a management, it is expected to reduce information asymmetry between management and shareholders, especially outside shareholders (Puspa et al, 2021). External ownership structure compares the number of public shareholders to the company's total shares. External ownership is calculated by the formula:

$$
\text { External Ownership }=\frac{\text { Shares owned by externals }}{\text { Number of outstanding shares }}
$$

\section{Dependent Variable}

The dependent variable is the main variable that becomes the attraction or focus of research (Chandrarin, 2017). The dependent variable in this research is profitability. Profitability as measured by using Return on Assets (ROA). ROA can be measured by comparing net income after tax divided by total assets (Darsono and Ashari, 2004).

\section{Results and Analysis}

Multiple linear regression analysis was used to determine the direction and magnitude of the influence of Good Corporate Governance on the profitability of consumer goods industry companies on the Indonesia Stock Exchange in 2019 - 2020 using SPSS 20.0. Multiple linear results for this research can be seen in table 1 as follows:

Table 1. $\mathrm{t}$ test results

\begin{tabular}{|c|c|c|c|c|c|c|c|c|}
\hline \multicolumn{9}{|c|}{ Coefficients $^{a}$} \\
\hline \multirow[t]{2}{*}{ Model } & & \multicolumn{2}{|c|}{$\begin{array}{c}\text { Unstandardized } \\
\text { Coefficients }\end{array}$} & \multirow{2}{*}{$\begin{array}{c}\text { Standardized } \\
\text { Coefficients }\end{array}$} & \multirow[t]{2}{*}{$\mathrm{t}$} & \multirow[t]{2}{*}{ Sig. } & \multicolumn{2}{|c|}{ Collinearity Statistics } \\
\hline & & $\mathrm{B}$ & Std. Error & & & & Tolerance & VIF \\
\hline \multirow{2}{*}{1} & (Constant) & -.136 & .505 & & -.269 & .789 & & \\
\hline & GCG & .288 & .532 & .054. & .541 & .590 & 1.000 & 1.000 \\
\hline
\end{tabular}

a. Dependent Variable: PROF 
Source: Processed secondary data, 2022

PROF $=-0,136+0,288$ GCG $+\mathrm{e}$

Explain :

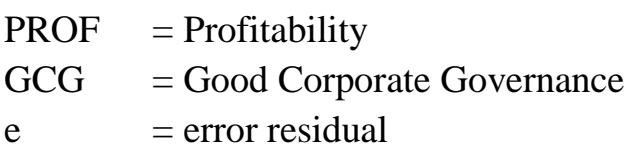

The multiple linear regression equation shows the direction of the independent variable (Good Corporate Governance) to the dependent variable (Profitability), where the regression coefficient of the independent variable which is positive means that it has a unidirectional effect on profitability. Based on the table, it can be seen that Good Corporate Governance has a positive influence on profitability. Based on the table, it can be seen that the value of the regression coefficient of Good Corporate Governance is 0.054 with a significance level of 0.590 . The significance results indicate that the significance level of Good Corporate Governance as measured by external party ownership is greater than the level of $=0.05$, so the hypothesis in this research is rejected, so it can be concluded that Good Corporate Governance as measured by external party ownership has a positive effect and does not. significant to profitability.

Puspito (2011) states that external ownership has no effect on the company's performance because it is unlikely that owners from outside the company are directly involved in the company's daily business affairs and supervise directly the management of the company by management. Kartika and Puspa (2013) state that the company's ownership structure will not reduce management performance to improve company performance. Putra and Fidiana (2017) state that large external ownership will cause management performance in managing the company to be less than optimal. Management of the company is less than optimal by management because the higher the ownership of outside parties, the greater the intervention on management performance, so that management feels bound and the space for management is increasingly limited.

Jensen and Meckling (1976) stated that agency theory implies the existence of information asymmetry between managers and company owners. Information asymmetry arises when managers know more about internal information and the company's prospects in the future when compared to shareholders and other stakeholders. This information asymmetry will cause managers as managers of the company to be able to control the company because they have more information than the shareholders, so that the ownership of outside parties does not guarantee that monitoring of management performance by parties from outside the company will run effectively. The results of this research are in accordance with research conducted by Puspito (2011), Putra and Fidiana (2017), and Puspa et al (2020) but are not in accordance with research conducted by Wiranata and Nugrahanti (2013), Agustina and Soelistya (2018), and Ali (2019).

Table 2. Coefficient of Determination

\begin{tabular}{|l|r|r|r|r|r|}
\hline Model & $\mathrm{R}$ & $\mathrm{R}$ Square & $\begin{array}{c}\text { Adjusted R } \\
\text { Square }\end{array}$ & $\begin{array}{c}\text { Std. Error of the } \\
\text { Estimate }\end{array}$ & Durbin-Watson \\
\hline 1 & $.054^{\mathrm{a}}$ & .003 & -.007 & .8336965 & 2.025 \\
\hline
\end{tabular}

a. Predictors: (Constant), GCG

b. Dependent Variable: PROF

Source: Processed secondary data, 2022

JURNAL ILMIAH KOMPUTERISASI AKUNTANSI Vol. 14, No. 2, Desember 2021 : $435-442$ 
From the coefficient data above, we can see that the adjusted R2 value is 0.003 , this means $0.3 \%$ of the variation in profitability can be explained from the independent variable Good Corporate Governance as measured by external ownership. While the rest $(100 \%-0.3 \%=99.7 \%)$ is explained by other reasons outside the model.

\section{Conclusion}

From the results of this research, it can be concluded that Good Corporate Governance which is measured by external ownership has no significant positive effect on profitability. Jensen and Meckling (1976) stated that agency theory implies the existence of information asymmetry between managers and company owners. Information asymmetry arises when managers know more about internal information and the company's prospects in the future when compared to shareholders and other stakeholders. This information asymmetry will cause managers as managers of the company to be able to control the company because they have more information than the shareholders, so that the ownership of outside parties does not guarantee that monitoring of management performance by parties from outside the company will run effectively. The value of adj R2 on profitability is 0,003 so that Good Corporate Governance which is measured by external ownership can explain the remaining only $0,3 \%$ can be explained by other variables. Therefore, in further research, other variables can be added, such as independent commissioner, managerial ownership, institutional ownership, audit committee and company size.

\section{References}

1. Agustina, H., \& Soelistya, D. (2018). Analisis Struktur Kepemilikan Perusahaan Terhadap Profitabilitas Perusahaan Makanan dan Minuman yang Terdaftar di BEI. Business and Finance Journal, 3(2), 85-94.

2. Ali, M. (2019). Pengaruh Kepemilikan Institusional, Kepemilikan Saham Publik, Umur Perusahaan, dan Ukuran Perusahaan Terhadap Profitabilitas Dengan Jumlah Bencana Alam Sebagai Variabel Moderasi. Jurnal Magister Akuntansi Trisakti, 6(1), 71-94.

3. Brigham, E.F., \& Houston, J. F. (2014) Dasar-dasar Manajemen Keuangan, Penerbit Salemba Empat, Jakarta.

4. Bursa Efek Indonesia, IDX Fact book BEI 2019.

5. Candradewi, I., \& Sedana, I. B. P. (2016). Pengaruh Kepemilikan Manajerial, Kepemilikan Institusional, dan Dewan Komisaris Independen Terhadap Return on Asset. E-Jurnal Manajemen Unud, 5(5), 3163-3190

6. Chandrarin, G. (2017). Metode Riset Akuntansi Pendekatan Kuantitatif, Penerbit Salemba Empat, Jakarta.

7. Darsono \& Ashari. (2005). Pedoman Praktis Memahami Laporan Keuangan, ANDI, Yogyakarta.

8. Ghozali, I. (2018). Aplikasi Analisis Multivariate dengan Program IBM SPSS 25 (Edisi 9), Badan Penerbit Universitas Diponegoro, Semarang.

9. Jensen, M. C., \& Meckling, W. H. (1976). Theory of The Firm: Manajerial Behavior, Agency Costs and Ownership Structure. Journal of Financial Economics, 3, 305-360.

THE INFLUENCE OF GOOD CORPORATE GOVERNANCE ON PROFITABILITY IN CONSUMER GOODS INDUSTRY COMPANIES LISTED ON THE INDONESIA STOCK 
10. Kartika, I., \& Puspa, A.M. (2013). Karakteristik Perusahaan sebagai Determinan Internet Financial and Sustainability Reporting. Jurnal Keuangan dan Perbankan, 17(2), 181-191.

11. Komite Nasional Kebijakan Governance. (2006). Pedoman Umum Good Corporate Governance di Indonesia. Komite Nasional Kebijakan Governance.

12. Organisation for Economic Cooperation and Development. (2004). Principles of Corporate Governance. Organisation for Economic Cooperation and Development.

13. Puspa, A.M., Sulistiyo, H., \&Sam'ani. (2021). Pengaruh Dewan Komisaris Independen Dan Kepemilikan Pihak Luar Terhadap Internet Financial Reporting Dengan Profitabilitas Sebagai Variabel Intervening Pada Perusahaan Manufaktur Yang Terdaftar di Bursa Efek Indonesia Tahun 2019. Jurnal Ekonomi, Manajemen, dan Akuntansi, 2(1), 34-44.

14. Puspito. (2011). Pengaruh Struktur Kepemilikan pada Kinerja Perusahaan dengan Struktur Modal sebagai Pemoderasi (Studi pada Perusahaan Makanan dan Minuman yang Terdaftar di BEI). Riset Manajemen \& Akuntansi, 2(3), 84-113.

15. Putra, B. P. D. (2015). Pengaruh Dewan Komisaris, Proporsi Komisaris Independen Terhadap Kinerja Perusahaan. Jurnal Manajemen Teori dan Terapan, 8(2), 70-85.

16. Putra, R.H., \& Fidiana. (2017). Pengaruh Tata Kelola Perusahaan terhadap Kinerja Keuangan Perusahaan. Jurnal Ilmu dan Riset Akuntansi, 6(8), 1-17.

17. Putri, M. N. A., \& Azizah, D. F. (2019). Pengaruh Ukuran Perusahaan, Leverage, dan Profitabilitas Terhadap Pelaporan Keuangan Melalui Internet (Internet Financial Reporting) (Studi pada Perusahaan Manufaktur Sub Sektor Industri dan Kimia yang Terdaftar di Bursa Efek Indonesia Periode 2017). Jurnal Administrasi Bisnis, 72(2), 205213.

18. Rini, T. S., \& Ghozali, I. (2012). Analisis Pengaruh Corporate Governance terhadap Kinerja Keuangan pada Perusahaan Manufaktur yang Terdaftar di BEI Tahun 2008-2010. Working paper. Jurusan Akuntansi Fakultas Ekonomi Universitas Diponegoro (tidak dipublikasikan).

19. Sugiyono. (2015). Metode Penelitian Kombinasi(Mix Methods), Alfabeta, Bandung.

20. Wiranata, Y. A., \& Nugrahanti, Y. W. (2013). Pengaruh Struktur Kepemilikan Terhadap Profitabilitas Perusahaan Manufaktur di Indonesia. Jurnal Akuntansi dan Keuangan, 15(1), 15-26.

21. ...... (2011) Peraturan Menteri Negara Badan Usaha Milik Negara Nomor PER01/MBU/2011, tentang Penerapan Tata Kelola Perusahaan yang Baik (Good Corporate Governance) pada Badan Usaha Milik Negara. 